\title{
都市空間における効率的な動線解析の共通基盤の あり方について
}

\author{
関本 義秀 1 ・薄井 智貴 $2 \cdot$ 金杉 洋 $3 \cdot$ 増田 祐介 4 \\ 1正会員 東京大学空間情報科学研究センター 特任准教授（†277-8568千葉県柏市柏の葉5-1-5） \\ 1E-mail:sekimoto@csis.u-tokyo.ac.jp \\ 2正会員 東京大学空間情報科学研究センター 特任助教（一277-8568 千葉県柏市柏の葉5-1-5） \\ ${ }^{2}$ E-mail:usui@csis.u-tokyo.ac.jp \\ 3非会員 東京大学生産技術研究所 特任研究員（干153-8505 東京都目黒区駒場4-6-1） \\ 3E-mail:yok@iis.u-tokyo.ac.jp \\ 4非会員 (株長大 社会事業本部（干114-0013 東京都北区東田端2-1-3） \\ 4E-mail: masuda-y@chodai.co.jp
}

\begin{abstract}
本研究では, ビジネスレベルでの利活用を念頭に置いた都市空間における多数の人々の位置データの品質の確保 とその処理のための共通基盤のあり方をまとめ, 人の動きに関して様々なところで行われる調查データの処理負担 を軽減することにより, 調查の迅速化・低コスト化を実現し, 現状の課題や将来像の議論等，より本質的な問題の 分析への注力を目指寸ものである. 具体的には，人の流れデータについてのニーズ・シーズを概観し，それらを踏 まえ実用レベルでの利活用を念頭においた上で, 効率的なデータの処理を行えるような動線解析プラットフォーム のWebAPIを定義・実装し，実際のパフォーマンス計測等を行い，実用上，概衩問題ないことを確認した.
\end{abstract}

Key Words : traffic flow analysis, common platform, people flow, WebAPI

\section{1.はじめに}

近年，都市内において，地震や火災発生あるいは 大規模イベント開催における混乱に伴う二次的災害 や，ターミナル駅等の交通結節点における混雑など を解消する必要性から，ダイナミックに時々刻々と 変動する多くの人々の流動を日常的に把握する必要 が出てきている．たとえば公共施設管理者のような, より安全, 快適な空間を構築し, 適切な交通政策を 立案する立場からは, ダイナミックに変化する人々 の動きを総合的すなわち面的に把握することが必要 不可欠である。 また，民間分野においてもたとえば 屋外広告では個別空間ごとに見られる頻度が異なる ため, 人の通行量に応じた場所ごとの価格体系等が 存在し, 無駄のない広告活動を支える重要な情報源 となっている.

一方で技術的には, 従来のパーソントリップ調查 のような統計調查による静的データに加え, 各種計 測技術の発展により，GPSを用いた個人の移動経路， CCTVカメラを用いた面的な人数，ICタグを用いた 自動改札による駅の乗降客数, 携帯電話基地局等へ
の端末登録数，あるいはデパートの時間帯別来場者 数など, 様々な切り口で人の移動について計測でき るようになってきている．また表示手法についても CG，GIS，CAD技術の進展により，都市圈全体の ような広域の二次元空間で多数の人の集中状況を俯 瞰したり, ターミナル駅内部のような狭域の三次元 空間での局所の人の動きの特性を分析するといった， よりリアリティを持たせつつ全体を視覚化すること も可能になってきている.

しかし，上記のような人々の動きに関する調査・ 計測の実データをビジネスレベルで流通可能にする には，大量のデータの品質をある程度そろえること が必要であり, 調查・計測からデータの加工・蓄積, 表示・提供に至るまで一連の流れをバランスよく効 率的に処理することが重要である。しかし実際に, そのような処理プロセスは, 非常に重要であり, か つ労力を要する部分であるにもかかわらず, 個々の ノウハウに依存してその場しのぎ的かつブラックボ ックス的に行われていることが多く，その結果とし て, 時間的にも費用的にも長期, 高コストとなり, 
最終的なビジネスレベルの利活用までに行き着くこ とはなくあまり議論されていないのが現状である.

従って本研究では，ビジネスレベルでの利活用を 念頭に置いた大量の人々の位置データの品質の確保 とその処理のための共通基盤のあり方について，二 一ズ，シーズ，社会的な役割分担などいくつかの主 要因からプロトタイプもまじえ概観した。具体的に は，人の移動データについての各分野のニーズや， シーズとしての既存技術や現在の課題を整理した

（2 章）。また，それらを踏まえ実用レベルでの利 活用を念頭においた上で, 効率的なデータの処理を 行う「動線解析プラットフォーム」を提案し, 基本 的な考え方や具体的な関数として WebAPI（API : Application Programming Interface）の構成を説明し た（3 章）. その後, パフォーマンスの妥当性やそ の利用例を説明し（4 章）, 最後に結論や今後の課 題を整理した（5 章）.

なお，著者らは2008年7月に東京大学空間情報科 学研究センターの中に「人の流れプロジェクト注 1)」を立ち上げ，その中で動線解析プラットフォー ムを運用してきた。本研究はその活動の一環であり， とくに動線解析のための共通基盤のあり方の側面に ついてまとめたものである.

\section{2. 人の移動に関するデータニーズと技術シーズ}

ここでは，まず，人の流れに関するデータのニー ズと技術シーズ，さらにそれらにもとづくデータ処 理技術について述べる.

\section{(1) 各分野における利活用}

\section{a) 交通分野における利活用}

人の流れのニーズは多岐にわたる。まず交通分野 の歴史は古く, パーソントリップ調査（以下, PT 調査と呼ぶ）注2), 1, 2) や大都市交通センサスのような 広域の流動を分析するものに始まり，最近ではある 特定の地域をGPS等の位置特定機器を用いて詳細に 分析するようなプローブパーソン調査がある（例え ば国内ではプローブパーソン研究会注3), 英国注4), 米国注5)など）。前者のPT調査等はある一日の行動 を調査し, 都市全体の中の典型的な流動を見るもの である一方, 後者のプローブパーソン調査は, 複数 日間の連続的な調査なども行いやすく, 人の属性に 地域の特性に応じた行動分析が行いやすい.

b) マーケティングにおける利活用

さらに，マーケティング・広告などへの利活用も ある。とくに, 屋外広告 ( OOH : Out Of Home media） ${ }^{3)}$, や最近出てきたデジタルサイネージ（電 子看板）は，注目を集めることに主眼があるため， 人の移動と密接な関係があり, 適切な出稿や事後評 価のために民間企業による移動に関する調査統計デ 一タの販売なども始まりつつある。例えば，首都 圈・関西圏を中心に, JR 東日本では， 3 年ごとに 1 万人調査が定期的に行われているし ${ }^{4)}$ ，ビデオリサ 一チ社の「屋外メディア総合調査（SOTO）」では 数千人レベルで鉄道・道路・街・店舗などの通過者
を調査している注 6). また，従来の地域の人口分布 ではなく，時間帯別の人口分布を具体的に算出し， 店舗数との関連を見た研究などもある ${ }^{5)}$.

\section{c) くらし・防災における利活用}

その一方で，災害の観点からの利用もある。東日 本大震災では，首都圈でも交通マヒにより徒歩で帰 宅する人で路上があふれかえる帰宅困難者が発生し た．帰宅困難者に関するシミュレーションはかねて から例えば新宿区で検討され，PT 調査データなど が使われていたが注 7)，想定以上の大規模な交通マ ヒにより，なかなか実態への対応は難しかった。こ うした状態には今後は,リアルタイムな状況を表す 携帯電話の位置情報や基地局レベルの集計情報など が効果的であろう。

\section{d) 医療・環境における利活用}

さらに医療・環境分野ではどうだろうか. 公衆衛 生の観点では, 2009 年の新型感染症を始めとして, 人の流れに対して, 感染症の拡大状況をシミュレー ションした研究がある ${ }^{6,7)}$. また，2010 年に国土交 通省都市・地域整備局で策定された「低炭素都市づ くりガイドライン」では，PT 調査から CO2 排出量 削減効果予測の手法がまとめられている注 8).

\section{(2) データ取得技術の進展}

一方で，データ取得技術については折に触れ紹介 されている ${ }^{8,9,10)}$. 主なものについて，既存データ／ 今後利用可能性のあるデータに, データ取得のタイ ミングとして定期的／イベント時のみという形に分 類して整理を行った（表-1）.とくに最近ではとく にSuica等のIC乗車券や携帯端末に乗降駅, 購買状 況などが記録されるようになり，それらを用いた研 究 ${ }^{11)}$ ，携帯基地局情報を用いた位置情報の収集を 行うセルラープローブ技術も欧米の企業で携帯電話 会社と連携を取る形で始まってきている ${ }^{12)}$.

とくにセルラープローブ技術はわかる位置精度と してはかなり粗いものであるが，リアルタイム情報 である点や基地局以外に追加のインフラ投資がいら ない点で有効であり，広域災害時への適用なども検 討も見られる ${ }^{13)}$. これらは主に自動車交通を対象に したものであるが，群衆を対象としたものもRattiら ${ }^{14)}$ の研究を始めに, Horanont $~^{15)}$, Urban Computing の分野に広がり始めている. なお，携带電話を使っ た人々の流動解析技術の最近の動向は, 別途, 関本

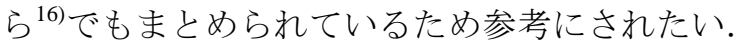

また，必ずしも調査機器を用いない形でも近年は インターネットを通じてアンケート調査を行う企業 が増加している注9)。それらは常時モニター（パネ ル）を数万人〜数十万人抱え，様々な形の謝礼によ ってインセンティブを確保するなどの形態が一般化 しており，それらを利用することも可能である。 
表-1 人の時空間位置に関する様々なデータ取得技術

\begin{tabular}{|c|c|c|}
\hline $\begin{array}{l}\text { データ取得 } \\
\text { タイミング }\end{array}$ & 定期的 & $\begin{array}{c}\text { イベント時のみ } \\
\text { (センサ設置個所のみ) }\end{array}$ \\
\hline 既存のデータ & GPS & $\begin{array}{l}\text { カメラ, VICS, ETC, } \\
\text { Web調査, POS, Wi-Fi }\end{array}$ \\
\hline $\begin{array}{l}\text { 利用可能性の } \\
\text { あるデータ }\end{array}$ & 携帯基地局情報 & ICカード, レーザー \\
\hline
\end{tabular}

\section{(3) 時空間データ処理技術の進展}

(1)のニーズや(2)の技術的シーズをふまえ, デー タの要件定義を行い, 状況に応じた時空間データの 作成を行うこととなる．例えば, Sekimoto et al.（20 11） ${ }^{17)}$ は断片的な時空間データではあるものの偏り のない大規模なサンプルデータを持つPT調査デー タを用いて, 最短経路ベースでネットワークデータ に沿った形で時空間内挿を行った「人の流れデー タ」を作成している（図-1）。

こうした生データを，ユーザーのニーズに合わせ た形で処理するサービスはクラウドの流れが強ま る中で，今後も増えると思われる. Google Transitだ けでなく, 商用のASPサービス注11)なども存在して いるが，乗換案内やマップマッチングなど単機能の ものが多く, 取得データの2次利用がしにくいケー スも多く, 学術的な意味も含めて動線解析全般に使 えるとはいいにくい，従って，技術をキャッチアッ プしつつ中立的な用途として大学の立場からこうし たサービスを実現することも社会的な役割として重 要なものと考えられる.

\section{3. プラットフォームの基本的な考え方}

前章のニーズ，シーズを踏まえ，本章では動線解 析プラットフォームの基本的考え方として，データ 定義, データベースやWebAPI の仕様を述べる.

\section{（1）データ定義とデータベース仕様}

前章のニーズを踏まえると，任意の時刻，任意の 空間範囲, 任意の人の位置を知りたい一方, 調査・ 計測データは定期的に数分間隔であったり, 計測で きた時のみになりがちである. 従って本研究では, データの時間解像度を 1 分間隔として稠密にするこ とを基本とし, データ取得のない時間帯は何かしら の内挿で埋めることとした。また空間は緯度・経度
で表現し，人ごとに ID を振ることとした（表-2）。 ただしこの ID はデータ内部の独自 ID であり，あく まで機械的なものである（以降，PID と呼ぶ）。

また，それらのデータは多量であり，(2)以降で 述べるような検索やマップマッチングのような基本 的な処理がWebAPIとして円滑にできるようにする には，適切なデータベース構造の設計なども必要と なる、時空間データベースそのものの研究も Wolfson et al. (1999) ${ }^{18)}$ な゙゙多数あるものの，ここ では単純な構造で高速な検索を実現するために，該 当オブジェクトを時空間検索で特定するための検索 用テーブルと，オブジェクト単位の属性や各時空間 位置のデータを保持したテーブルの2層構造とした。

図-2は具体的にSekimoto et al.で実際に調査対象の 属性（PERSON）やトリップ（TRIP），サブトリッ プ（SUBTRIP），各ポイント（POINT）等を含む PTデータを上記テーブル構成に従って格納した手 順である。実際に2011年12月現在で東京都市圈をは じめとして，14都市圈（15調査）のデータを提供し ており，例えば東京のPT調查データ（平成 10 年 度）は約72万人，すなわち72万PIDのデータがあり， オブジェクトテーブルでは，全PIDをそれぞれ一行 ずつ格納し，カラム方向で1日全てを1分ごとの時空 間位置に分けている（ただし，データベースソフト の都合上，ここでは，午前と午後で2つのテーブル に分かれている）。また，時空間検索用テーブルで は，とくに時間断面での検索を強化するために，時 間ごとにテーブルを分けて作成するとともに，

$\lceil\mathrm{PID}$ の」「PID, 緯度, 経度」「PID, メッシュ 番号」に対してインデキシングを行った.

表-2 時空間データの定義

\begin{tabular}{c|l|l|l}
\hline PID & \multicolumn{1}{|c|}{ Time } & \multicolumn{1}{c}{ Longitude } & \multicolumn{1}{c}{ Latitude } \\
\hline 1 & $\ldots$ & $\ldots$ & $\ldots$ \\
\hline$\ldots$ & $\ldots$ & $\ldots$ & $\ldots$ \\
\hline 5 & $0: 00$ & 139.88325 & 35.66349 \\
\hline$\ldots$ & $\ldots$ & $\ldots$ & $\ldots$ \\
\hline 5 & $8: 15$ & 139.88325 & 35.66349 \\
\hline 5 & $8: 16$ & 139.87834 & 35.66334 \\
\hline$\ldots$ & $\ldots$ & $\ldots$ & $\ldots$ \\
\hline 5 & $23: 59$ & 139.88325 & 35.66349 \\
\hline 6 & $\ldots$ & $\ldots$ & $\ldots$ \\
\hline$\ldots$ & $\ldots$ & $\ldots$ & $\ldots$ \\
\hline
\end{tabular}

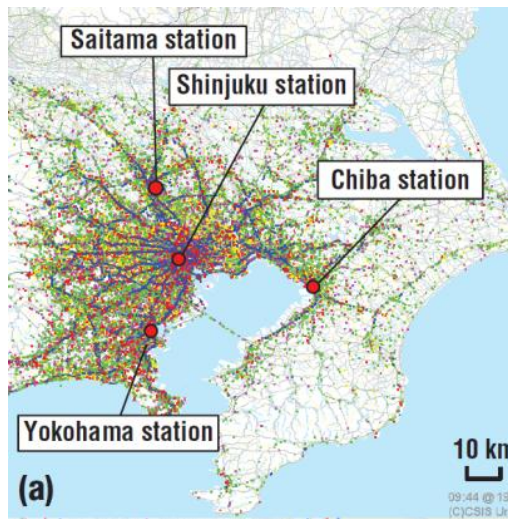

図-1

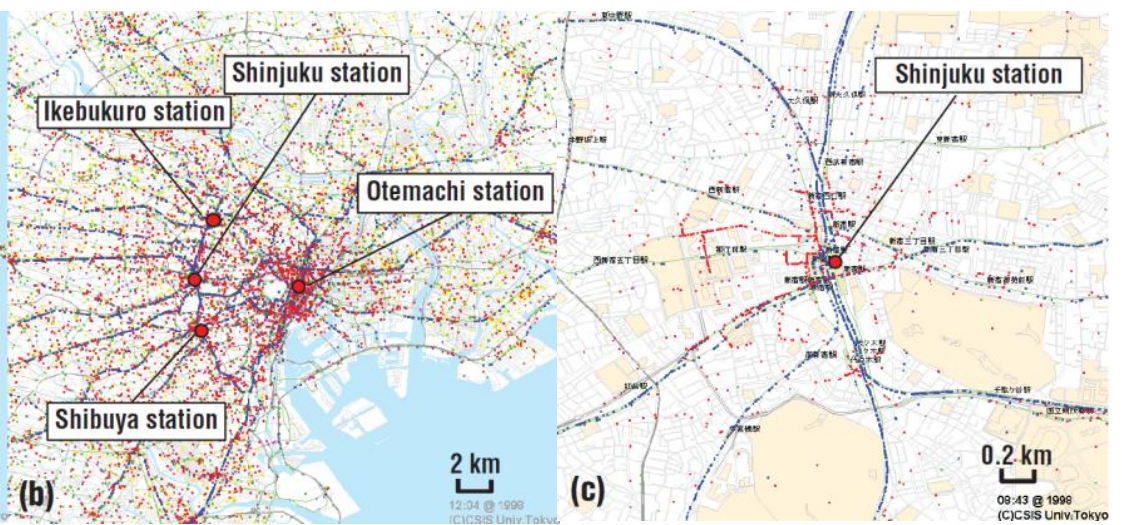

(c)

(Sekimoto et al. (2011) $)^{17)}$ をとに作成．青は鉄道，赤は徒歩，黄緑は自家用車，黄色が自転車による移動） 


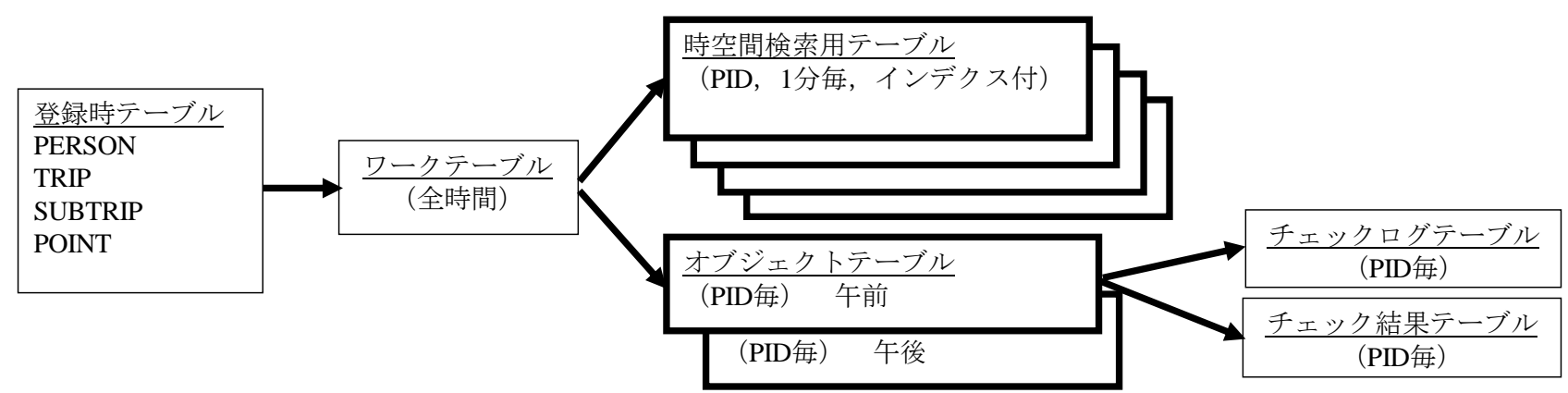

オブジェクトテーブル

(全PID分を 1 つのテーブルに格納)

\begin{tabular}{|c|c|c|}
\hline カラム項目 & $\begin{array}{l}\text { データ型 } \\
(\text { 桁数 })\end{array}$ & データ例 \\
\hline PID & $\mathrm{VC}(10)$ & 34748 \\
\hline 性別 & $\mathrm{C}(1)$ & 1 \\
\hline 年齢 & $\mathrm{VC}(3)$ & \\
\hline 住居地（ゾーンコード） & $\mathrm{VC}(10)$ & 10701301 \\
\hline 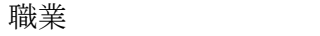 & $\mathrm{C}(2)$ & \\
\hline 拡大係数 & $\mathrm{N}(6,0)$ & 12 \\
\hline 拡大係数その2 & $\mathrm{N}(6,0)$ & 12 \\
\hline $\begin{array}{l}\text { 時刻T0000のデータ } \\
\text { トリプ悉员 +ブト }\end{array}$ & $\mathrm{VC}(255)$ & 1199071 \\
\hline リップ番号, 移動目的 & & $\begin{array}{l}1,1,99,91,1 \\
30.732647,\end{array}$ \\
\hline $\begin{array}{l}\text { コード, 交通手段コー } \\
\text { ド,経度,緯度 (カンマ } \\
\text { 区切り) (※1) }\end{array}$ & & 33.833945 \\
\hline $\begin{array}{l}\text { 時刻T0001のデータ } \\
\text { 同上 } \\
\text { ‥・ }\end{array}$ & $\mathrm{VC}(255)$ & • • \\
\hline $\begin{array}{l}\text { 時刻T2359（※2） } \\
\text { 同上 }\end{array}$ & $\mathrm{VC}(255)$ & • • \\
\hline
\end{tabular}

(※1）交通手段変化点で2点ある場合は/で区切るものとする

（※2）実際には，DBソフトの制約上，午前と午後で テーブルを分けている

$(※ 3)$ VC : 可変長文字列, C : 固定長文字列,

$\mathrm{N}$ : 数值 (桁数, 小数点以下桁数), DATE : 日付と時刻

(※4）下線のカラム項目は主キー

図-2 PT調査データをもとに人の流れデータを格納した際のデータベースのテーブル構造

（上 : 各テーブル作成のフロー，下：WebAPIで参照するオブジェクトテーブルと時空間検索テーブル）

\section{(2) WebAPIの構成}

一方で，前節のプラットフォームの利用場面を考 えると, 大きく分けて，予めきちんとデータベース 化されたデータをユーザーが効率的に使うための

「データ提供機能」と，ユーザーが持つデータを自 らマップマッチングや得られない時間帯の空間デー タを何らか補間する「データクリーニング機能」が ある. 具体的には, 前者はデータの時空間検索のよ うな機能が必要とされ, 後者はマップマッチング, 経路検索，時空間内挿，データチェック等の機能が 必要である。実際の利用場面では, あるアルゴリズ 厶を実装するために様々な基本的な処理関数を組み 合わせて使えるよう，こうした関数が一通り準備さ れていることが重要であり, 本研究ではこれらの関 数をWebAPIとして用意することとした（表-3）。 詳細は(4)以降で説明するが「人の流れプロジェク ト」サイト内でもWebAPI仕様書として公開すると ともに，「時空間データクリーニングサービス」と 「時空間データ提供サービス」の 2 種類に分け, サ
時空間検索用テーブル (時間ごとにテーブルを作成)

\begin{tabular}{|c|c|c|}
\hline カラム項目 & $\begin{array}{l}\text { テータ型 } \\
\text { (桁数) }\end{array}$ & データ例 \\
\hline PID & $\mathrm{VC}(10)$ & 63333 \\
\hline トリップNO & $\mathrm{N}(8)$ & 2 \\
\hline サブトリップ NO & $\mathrm{N}(8)$ & 5 \\
\hline 且時 & DATE & $00-10-02$ \\
\hline 経度 & $\mathrm{N}(15,10)$ & 141.583566 \\
\hline 緯度 & $\mathrm{N}(15,10)$ & 42.909082 \\
\hline 時間間隔 & $\mathrm{N}(2)$ & 1 \\
\hline メッシュ番号 & $\operatorname{VC}(15)$ & $5235-57-62-1711$ \\
\hline オリジナルフラグ & $\mathrm{C}(1)$ & 1 \\
\hline 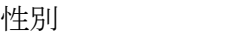 & $\mathrm{C}(1)$ & 1 \\
\hline 年齢 & $\mathrm{VC}(2)$ & 15 \\
\hline 住所 & $\mathrm{VC}(10)$ & 21711601 \\
\hline 職業 & $C(2)$ & 11 \\
\hline 目的 & $\mathrm{C}(2)$ & 99 \\
\hline 拡大係数 & $\mathrm{N}(6)$ & 29 \\
\hline 拡大係数その2 & $\mathrm{N}(6)$ & 29 \\
\hline 交通手段 & $\mathrm{C}(2)$ & 97 \\
\hline 出発日時 & DATE & $00-10-02$ \\
\hline 到着日時 & DATE & $00-10-02$ \\
\hline 登録日時 & DATE & $10-01-13$ \\
\hline 調査ID & $\mathrm{VC}(5)$ & 98TKY \\
\hline
\end{tabular}

ービス提供している.

\section{(3) 利用するインフラデータ}

前節で述べたような様々な処理には道路や鉄道の ネットワークや時刻表等，いくつかなインフラに関 する基盤データが必要となる。ここでは，道路と鉄 道のネットワークデータとしてDRMデータ（Digital Road Map : デジタル道路地図協会）注12)を用いる。 DRMデータは全道路まで含めると全国で総延長約 89万kmをカバーし，約487万リンク存在している （2011年3月末）。

なお，DRMデータの道路部はノード・リンクの 位相構造を構成寸るネットワーク以外に幾何形状の 豊かさを確保するために，1つのリンクにいくつか の補間点が存在している. 従って, 道路の経路探索 にはノード・リンクの位相構造を用いる一方, マッ プマッチングや時空間内挿の一部では, 幾何形状の 詳細さを確保するために補間点を用いる.

その一方で，DRMデータは鉄道のネットワーク 
はあるものの位相構造やそれに伴う所要時間等の属 性はなく, 路線の幾何構造のみである. 従って, 鉄 道の経路探索では, 何らかの時刻表データベースが 必要であるものの, 時刻表データベースそのものは 非常に高価であるため, 本研究では「駅すぱあと

(侏ヴァル研究所）」注13)の鉄道経路所要時間デー タを用いる。ただし，所要時間データのみを利用す る欠点として，鉄道の運行がない，または非常に少 ない時間帯でもすぐに移動してしまう点が挙げられ る.また，マップマッチングや時空間内插の一部は 道路と同様にDRMの幾何構造のデータを用いる. このように，鉄道の場合，経路を求める時刻表と時 空間内挿等で用いる幾何構造は全く違うデータであ
るため, 駅名の表現等が多少異なり, 組み合わせて 使う場合は注意が必要となる。本研究では，これら をつなぐ対応テーブルを作成している.

なお，日本国内だけでなく，海外で同様のことを 行う際にもこうしたインフラデータは必要であり, 極力汎用的なものが使えるとよい. 最近はボランテ イアによって整備が進みつつある, フリーのOpen Street Mapデータ（OSMデータ） 注14)が位相構造を構 築しやすいため, 本研究ではそれをネットワークデ 一タとして用いる。これらネットワークデータの位 相構造や幾何構造の量について Sekimoto et al. を元 に東京と八ノイの比較をまとめたものが表-4である.

表-3 主要なWebAPIの仕様概略

\begin{tabular}{|c|c|c|c|c|c|}
\hline \multirow{2}{*}{\multicolumn{2}{|c|}{ API }} & \multirow{2}{*}{ 機 能 } & \multicolumn{3}{|c|}{ 入力／出力 } \\
\hline & & & \multicolumn{2}{|l|}{ 入力 } & 出力 \\
\hline $\begin{array}{l}\text { マップマ } \\
\text { ッチング }\end{array}$ & $\begin{array}{l}\text { 任意点の道路近傍点取得 } \\
\text { 【GetNearestRoadPoint】 }\end{array}$ & $\begin{array}{l}\text { 任意の点座標より, 道路 } \\
\text { ネットワークにおけるそ } \\
\text { の位置の近傍座標を, ネ } \\
\text { ットワーク補間点レベ } \\
\text { ルで取得する. }\end{array}$ & $\begin{array}{l}\text { ・点座標 } \\
\text { - 道路種別 } \\
\text { ・路線番号 }\end{array}$ & $\begin{array}{l}{[\text { 必須 }]} \\
{[\text { オプション] }} \\
\text { [オプション] }\end{array}$ & $\begin{array}{l}\cdot \text { 近傍点座標 } \\
\cdot \text { 道路種別 } \\
\cdot \text { 路線番号 } \\
\cdot 2 \text { 次メッシュコード }\end{array}$ \\
\hline \multirow[t]{3}{*}{ 経路探索 } & $\begin{array}{l}\text { 道路の経路探索（点座標 } \\
\text { 指定） } \\
\text { 【GetRoadRoute】 }\end{array}$ & $\begin{array}{l}\text { 任意の点座標（起点, 終 } \\
\text { 点, 経由点) より, それ } \\
\text { ら地点を結ぶ道路上の最 } \\
\text { 短経路を取得する. }\end{array}$ & 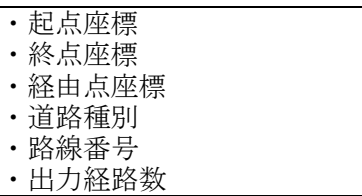 & $\begin{array}{l}\text { [必須] } \\
{[\text { 必須] }} \\
{[\text { オプショノ] }} \\
{[\text { オプション] }} \\
{[\text { オプション] }} \\
\text { [オプション] }\end{array}$ & $\begin{array}{l}\text { ・経路座標リスト } \\
\text { ・経路延長 }\end{array}$ \\
\hline & $\begin{array}{l}\text { 鉄道の経路探索（駅指 } \\
\text { 定, 点座標指定） } \\
\text { 【GetRailRoute】 }\end{array}$ & $\begin{array}{l}\text { 任意の駅（起点, 終点, } \\
\text { 経由点）より, それら地 } \\
\text { 点を結ぶ鉄道上の最短経 } \\
\text { 路を取得する. }\end{array}$ & $\begin{array}{l}\text { ・起点駅（駅名または座標） } \\
\text { ・終点駅（駅名または座標） } \\
\text { ・位置単位指定 } \\
\text { （駅名または座標） } \\
\text { ・経由駅（駅名または座標） } \\
\text { ・出発／到着日時 }\end{array}$ & $\begin{array}{l}\text { [必須] } \\
\text { [必須] } \\
\text { [必須] } \\
\text { [オプショソ] } \\
\text { [オプション] }\end{array}$ & $\begin{array}{l}\text { ・経路座標リスト } \\
\text { ・通過駅 } \\
\text { ・駅出発／到着日時 }\end{array}$ \\
\hline & $\begin{array}{l}\text { 鉄道の経路探索（鉄道駅 } \\
\text { までの道路の経路探索含 } \\
\text { む) } \\
\text { 【GetMixedRoute】 }\end{array}$ & $\begin{array}{l}\text { 任意の点座標（起点, 終 } \\
\text { 点, 経由点) より, それ } \\
\text { ら地点を結ぶ道路及び鉄 } \\
\text { 道経路を取得する. }\end{array}$ & $\begin{array}{l}\cdot \text { 起点座標 } \\
\text { ・終点座標 } \\
\text { ・経由点座標 }\end{array}$ & $\begin{array}{l}\text { [必須] } \\
\text { [必須] } \\
\text { [オプション] }\end{array}$ & $\begin{array}{l}\text { ・経路座標リスト } \\
\text { ・通過駅 }\end{array}$ \\
\hline $\begin{array}{l}\text { 時空間内 } \\
\text { 挿 }\end{array}$ & $\begin{array}{l}\text { 時空間内挿の実施 } \\
\text { 【GetSTInterpolatedPoint】 }\end{array}$ & $\begin{array}{l}\text { 任意の時空間位置 (起 } \\
\text { 点, 終点の時空間位置) } \\
\text { よりそれらを内挿する } \\
\text { 時空間位置を取得する. }\end{array}$ & $\begin{array}{l}\text { ・起点日時 } \\
\text { ・終点日時 } \\
\text { ·起点座標 } \\
\text { • 終点座標 } \\
\text { · 内挿時間間隔 }\end{array}$ & $\begin{array}{l}\text { [必須] } \\
\text { [必須] } \\
\text { [必須] } \\
\text { [必須] } \\
\text { [オプショソ] }\end{array}$ & ・時空間位置座標リスト \\
\hline \multirow[t]{4}{*}{$\begin{array}{l}\text { データ検 } \\
\text { 索 }\end{array}$} & $\begin{array}{l}\text { 時空間検索に該当する } \\
\text { PID リスト取得 } \\
\text { 【GetPIDList】 }\end{array}$ & $\begin{array}{l}\text { 時空間内挿済みの登録 } \\
\text { PT ータ， 検索条件に } \\
\text { 一致する PID リストを取 } \\
\text { 得する }\end{array}$ & $\begin{array}{l}\cdot \text { 調査 ID } \\
\text { ・時空間範囲 } \\
\text { ・属性 } \\
\text { •オブジェクトの選択 } \\
\text { [全数かランダムサンプル] } \\
\text { ・指定条件 通過または滞在 }\end{array}$ & $\begin{array}{l}\text { [必須 }] \\
{[\text { 必須 }]} \\
\text { [オプショソ } \\
\text { [オプション] } \\
\text { [オプショソ }\end{array}$ & $\begin{array}{l}\text { •PID リスト } \\
\text { (区切り文字つき) }\end{array}$ \\
\hline & $\begin{array}{l}\text { PID に該当するオブジェ } \\
\text { クトデータの取得 } \\
\text { 【GetFlowData】 }\end{array}$ & $\begin{array}{l}\text { 時空間内挿済みの登録 } \\
\mathrm{PT} \text { ○゙ータから，PID を指 } \\
\text { 定し，該当する PID の指 } \\
\text { 定時間範囲分のデータセ } \\
\text { ッを取得する. }\end{array}$ & $\begin{array}{l}\cdot \text { 調査 ID } \\
\text { • PID } \\
\text { • 開始日時 } \\
\text { • 終了日時 }\end{array}$ & $\begin{array}{l}\text { [必須] } \\
\text { [必須] } \\
\text { [必須] } \\
\text { [必須] }\end{array}$ & $\begin{array}{l}\text { • 時空間位 置座標リスト } \\
\text { (指定時間範囲分) }\end{array}$ \\
\hline & $\begin{array}{c}\text { 時空間位置情報の取得 } \\
\text { 【GetDistributionData】 }\end{array}$ & $\begin{array}{l}\text { 時空間内挿済みの登録 } \\
\mathrm{PT} \text { 一タから，指定し } \\
\text { た検索条件と一致する } \\
\text { 人々の時空間位置に関す } \\
\text { る情報を取得する. }\end{array}$ & $\begin{array}{l}\text { - 調査 ID } \\
\text { ・検索条件 }(* 1)\end{array}$ & $\begin{array}{l}{[\text { [オプショソ }} \\
{[\text { オプション] }}\end{array}$ & $\begin{array}{l}\text { •時空間位置座標リスト } \\
\text { ・レスポンスリスト }\end{array}$ \\
\hline & $\begin{array}{l}\text { 時空間位置画像の取得 } \\
\text { 【GetDistributionImage】 }\end{array}$ & $\begin{array}{l}\text { 時空間内挿済みの登録 } \\
\text { PTデータから, 指定し } \\
\text { た検索条件と一致する } \\
\text { 人タの時空間位置に関す } \\
\text { る情報について, ネット } \\
\text { ワークデータを背景とし } \\
\text { た画像として取得する. }\end{array}$ & $\begin{array}{l}\text { - 調査 ID } \\
\text { - 検索条件 (*1) }\end{array}$ & $\begin{array}{l}{[\text { [オプショソ] }} \\
\text { [オプショソ] } \\
\text { [必須] } \\
\text { [必須] }\end{array}$ & - 出力画像 \\
\hline
\end{tabular}

*1 検索条件は, 以下の通りである. 実際に指定する值等詳細については動線解析プラットフォームWebAPI 仕様書を参照のこと.

【空間指定 (任意)】中心座標 (経度, 緯度), 距離単位指定, 縦距離, 横距離 【日付指定 (必須)】日付, 時刻【属性指定 (任

意) 】交通手段, 性別, 年齢 
表-4 インフラデータの構成例（東京都市圏とハノイ都市圏のケース）

\begin{tabular}{|c|c|c|c|c|}
\hline \multirow{2}{*}{ 都市圈 } & \multicolumn{2}{|c|}{ 道路 } & \multicolumn{2}{|c|}{ 鉄道 } \\
\hline & 位相構造 & 幾何構造 & 位相構造 & 幾何構造 \\
\hline 東京都市圏 & $\begin{array}{l}\text { 約 } 133 \text { 万ノードと約 } 191 \text { 万 } \\
\text { リンク (DRM) }\end{array}$ & 約 678 万補間点（DRM） & 1,455 駅（DRM） & 約 5 万補間点（DRM） \\
\hline ハノイ都市圈 & $\begin{array}{l}\text { 約 } 5,600 \text { ノードと } 3,600 \text { リン } \\
\text { ク (OSM) }\end{array}$ & 約 2.4 万補間点（OSM） & --- & --- \\
\hline
\end{tabular}

\section{(4) マップマッチング機能}

マップマッチング機能は，GPS データなどのクリ ーニングを念頭に，道路ネットワークデータ

（DRM データ）に対して行い，最も近い補間点を 含むリンクの垂線の足を取得している ("GetNearestRoadPoint"）。なお探索は入力点より $1 \mathrm{~km}$ 以内の範囲に対して行い, 半径 $1 \mathrm{~km}$ 以内にネ ットワークデータが見つからない場合はエラーとな る.

もともと歩行者のためのマップマッチングのアル ゴリズムとして小島ら ${ }^{19)}$ ，三輪ら ${ }^{20)}$ な゙゙があり， 例えば時間的に連続した GPS データの場合は，位 置的に近傍のネットワークを重点的に探索すること によって効率化が得られる場合もあるものの, 大量 の様々な場所の位置データを処理することもあり得 るため, 本研究は該当する補間点の検索を効率化す るために, DRM データを 2 次メッシュ単位でテー ブルを分けることで対応している.

ただし, 本研究の場合, 高速道路を走行した場合 は，IC 以外の場所でマッチングしてしまうことも あるため，その点は今後改良が必要である.

\section{(5) 経路探索機能}

経路探索機能は, 任意の起終点・経由点を入力し それらを結ぶ道路上の最短経路を返す "GetRoadRoute" と, 任意の駅を入力しそれらを結ぶ 鉄道上の最短経路を返す"GetRailRoute" と, 長距離 移動は鉄道を使いつつ, 最寄までは道路を使って移 動する"GetMixedRoute"の 3 種類を用意している. 道路上の最短経路を求める際には(3)で述べたよう に，DRM の位相構造（ノード・リンク）を用い， 鉄道上の最短経路を求める際には「駅すぱあと」の 鉄道経路所要時間データを用いている.

なお，道路の経路探索は基本的には時間最短であ り，アルゴリズムレベルでは，現在はシンプルに Djikstra 法で最短経路探索を用いて行っているが処 理速度の都合上, 全国のネットワーク分は全てオン メモリで処理している。また，各リンクの通行にお ける所要時間はリンク長／速度であるが，速度は， PT 調査のように予め交通手段がわかっている場合 は，付録の表-1のような道路種別と交通手段に応じ た速度を用いている。

\section{(6) 時空間内挿機能}

時空間内挿機能（"GetSTInterpolatedPoint"）は，2 地点の時空間位置を入力し, それらを結ぶ最短経路 を与えた時間の中で等速度で移動するとし, 指定し た時間間隔で時空間位置列を返すものである。
時空間内挿機能は，前節の経路探索で求められる 位相構造レベル（道路で言えばノードレベル，鉄道 でいえば駅レベル）に比べ，より詳細な時間間隔を 入力した時（例えば 1 分間隔）は，ノード間や駅間 を直線，あるいは道路や鉄道の幾何構造に沿って内 挿することになるため，計算時間も多くなるものの 詳細性・リアリティが保たれる。図-3 は 3 つのサ ブトリップを持つある人の動きをサブトリップごと に 1 分間隔で時空間内挿したものである.

このような機能については，おそらく従来は経路 探索の範囲で行われていたと思われるが，多数の移 動体の分布を時間断面で見たいという場合は各時間 ごとに位置情報を求めなおす必要があり，とくに都 市内の道路や建物が密集している空間の場合は，単 純な直線内挿を行うと, 道路や鉄道上を通らず, 建 物内を突き抜けるような移動が多発してしまい, こ うした分布が混在しないことが重要であり，必要性 が高いにも関わらずそのような研究はなかったとい える.

\section{(7) 時空間検索機能}

時空間検索機能は，サーバーに何らか格納されて いる人の時空間データを時間・空間・属性で，検索 し該当 PID を取り出すものである。(1)でも触れた ように，例えば東京都市圈の人の流れデータは 72 万人分の 1 分間隔の時空間位置データが属性ととも に格納されており大変膨大であるため, 時空間検索 用テーブルとオブジェクトテーブルの 2 種類のテー ブルで効率化し，それぞれの検索にも実時間で対応 できるようにしている。

また，時空間検索の利用をいくつかのタイプに分 けて, WebAPI（GetPIDList）の挙動をまとめたも のが表-5である。時間を限定して，時間断面での人 の分布状態を求めるタイプ 1 , 空間を限定し, そこ を通過・滞在する人（来街者調査（図-4）やセンサ ス観測地点などを想定）を求めるタイプ 2, 属性を 絞った形で検索を行うタイプ 3 などがある。さらに， タイプ 2 の通過・滞在はそれぞれ，少しでも通った 人, ずっといた人と本研究では定義している（タイ プ 4）.そして，ランダムでサンプル抽出した人の 挙動を見るようなこともできる（タイプ 5）.

GetPIDList で当該 PID を特定した後，その PIDの オブジェクトデータ（例えば一日の動き）を取り出 すものが GetFlowData である。図-4 は来街者調査の イメージで，東京都市圈の人の流れデータ（平成 10 年度）の登録データ 72 万人の中から朝 9 時に渋 

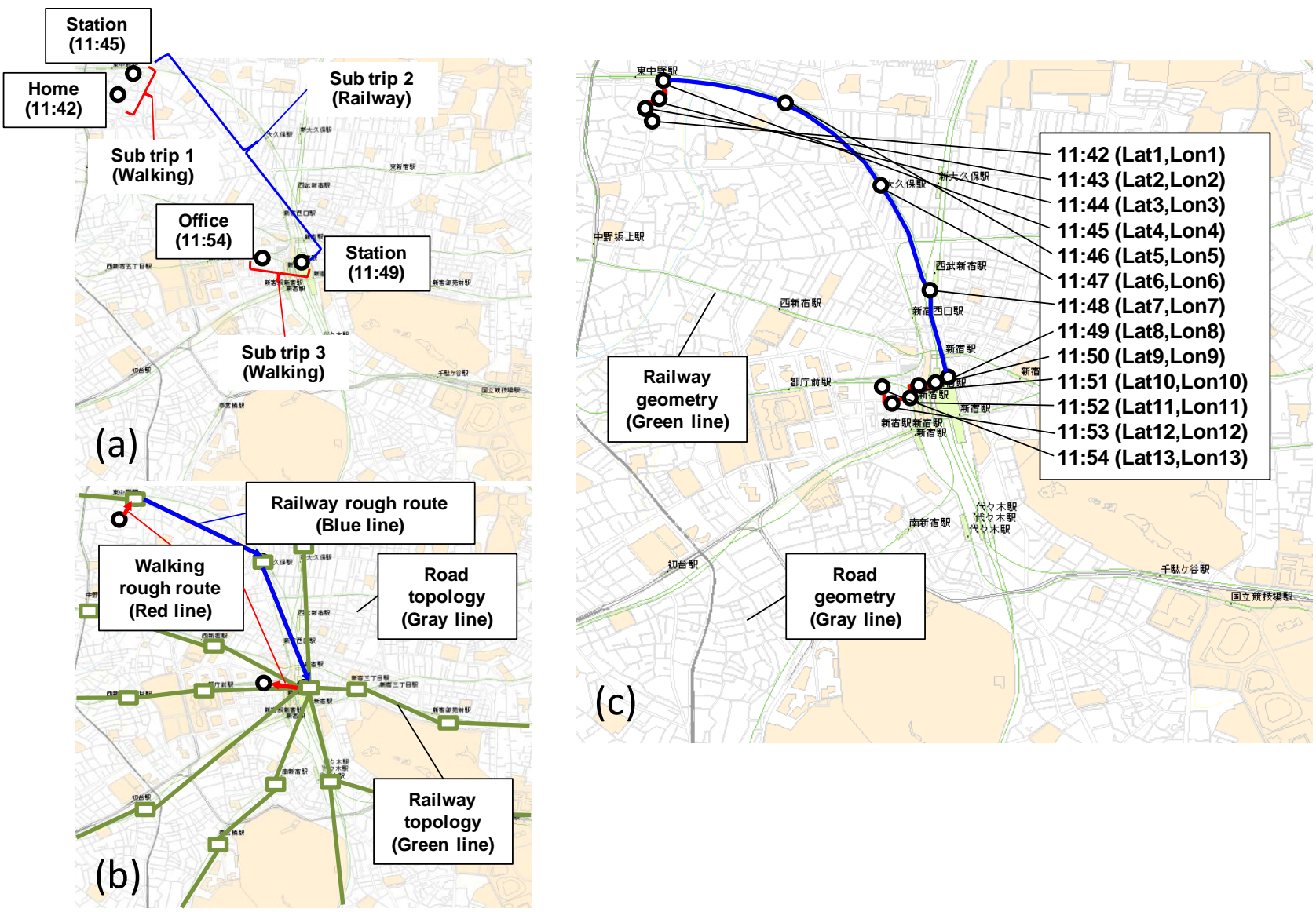

図-3 ある人のトリップのサブトリップの OD の時空間位置から 1 分間隔の位置を求めたもの時空間内挿の例

(Sekimoto et al.を引用)

谷駅を中心とした $1 \mathrm{~km}$ の矩形範囲内で滞在してい る人（通過は含めない）を GetPIDListで抽出したと ころ 538 人が抽出され, GetFlowDataを用いて各人 の 1 日の経路を赤く描いたものである. 渋谷なので, 色々な地域から満遍なく人が来ていることがわかる が，とくに渋谷が都心では西の地域にあるため，や や西方面から来ている人が多いことも読み取れる。

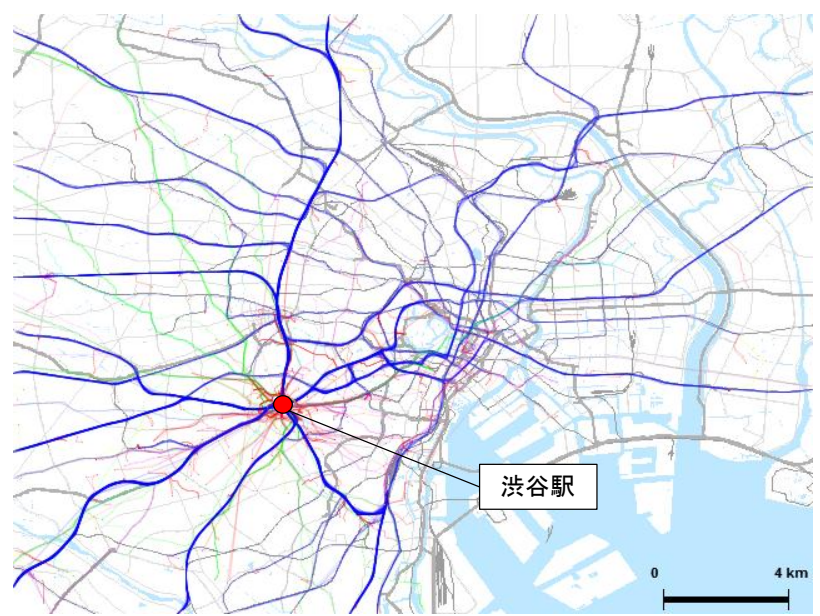

図-4 GetPIDList を用いて渋谷の来街者サンプル 538 人の 1 日の経路を描いたもの. (平成 10 年の人の流れデ 一タ 72 万人に対し，朝 9 時に渋谷駅を中心に $1 \mathrm{~km}$ 四方に存在した人を抜き出した。青 : 鉄道，黄緑： 個人車両，紫：商業車両，赤：徒歩)
また，基本的には，該当する時空間データそのも のを検索・ダウンロードして，それぞれで分析等を 行うことを想定するものの，背景地困がない場合な どは背景画像とセットで分布状況を画像化すること も有用であり，GetDistributionImage はそのようなこ とを行う WebAPI である。図-5 は，渋谷駅 $5 \mathrm{~km}$ 四 方の朝 9 時の分布状況を描いたものである。通勤等 で人が集中していることが読み取れる.

なお，人の流れデータ取得に関わる時空間検索関 係は，個人情報保護のため，人の流れプロジェクト 内で利用申請が必要なことを補足する。

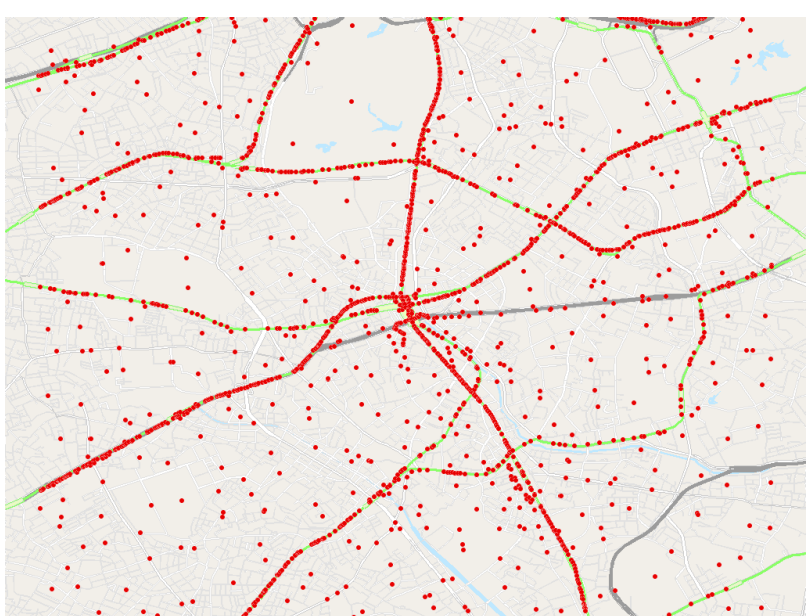

図-5 GetDistributionImage を用いて渋谷駅周辺の $5 \mathrm{~km}$ 四方 の朝 9 時の分布状況を描いたもの（赤色の点） 
表-5 時空間検索の主な利用タイプとWebAPI の挙動特性

\begin{tabular}{|c|c|c|}
\hline 検索のタイプ & 利用イメージ & GetPIDList の挙動 \\
\hline $\begin{array}{l}\text { (タイプ1) } \\
\text { 時間を限定し } \\
\text { て時空間検索 } \\
\text { する }\end{array}$ & $\begin{array}{l}\text { 時間断面での人 } \\
\text { の分布状態を求 } \\
\text { める }\end{array}$ & $\begin{array}{l}\text { 時間ごとに検索テーブルが } \\
\text { あるで時間の特定は容 } \\
\text { 易. 空間範囲が全域の場合 } \\
\text { は特定は不要であるが結果 } \\
\text { 出力に時間がかかる. }\end{array}$ \\
\hline $\begin{array}{l}\text { (タイプ2) } \\
\text { 空間を限定し } \\
\text { て時空間検索 } \\
\text { する }\end{array}$ & $\begin{array}{l}\text { ある場所を通 } \\
\text { 過・滞在する人 } \\
\text { をカウントする } \\
\text { (来街者調查や } \\
\text { センサス観測地 } \\
\text { 点でのカウント } \\
\text { など) }\end{array}$ & $\begin{array}{l}\text { 時間範囲が長期にわたる時 } \\
\text { は複数のテーブルをあたる } \\
\text { ので，その分時間がかか } \\
\text { る.空間範囲がビンポイン } \\
\text { トであれば, } 2 \text { 次メッシュレ } \\
\text { ベルで少数に特定できるの } \\
\text { で早い. 広域を対象とする } \\
\text { とやや時間がかかる. }\end{array}$ \\
\hline $\begin{array}{l}\text { (タイプ 3) } \\
\text { 属性による検 } \\
\text { 索 }\end{array}$ & $\begin{array}{l}\text { ある属性の人を } \\
\text { 取り出す }\end{array}$ & 各属性で絞っている \\
\hline $\begin{array}{l}\text { (タイプ 4) } \\
\text { 通過と滞在を } \\
\text { 区別して検索 } \\
\text { する }\end{array}$ & $\begin{array}{l}\text { 少しでも通った } \\
\text { 人をカウント } \\
\text { (通過)，常に } \\
\text { いた人をカウン } \\
\text { トする (滞在) }\end{array}$ & $\begin{array}{l}\text { 滞在の場合, 全ての時間範 } \\
\text { 囲内で存在していること文 } \\
\text { 確認するため時間がかか } \\
\text { る. }\end{array}$ \\
\hline $\begin{array}{l}\text { (タイプ 5) } \\
\text { ランダムに人 } \\
\text { を取り出す }\end{array}$ & $\begin{array}{l}\text { サンプル抽出し } \\
\text { た人の挙動を見 } \\
\text { る }\end{array}$ & PID をランダムにしている \\
\hline
\end{tabular}

\section{4. ケーススタディ}

\section{(1) システムの概要}

本システムは，HTTPリクエストベースでやり取 りすることとし，WebサーバとDBサーバを組み合 わせ，Java1.6をベースに構築した（詳細は図-6，表 -6を参照のこと）.

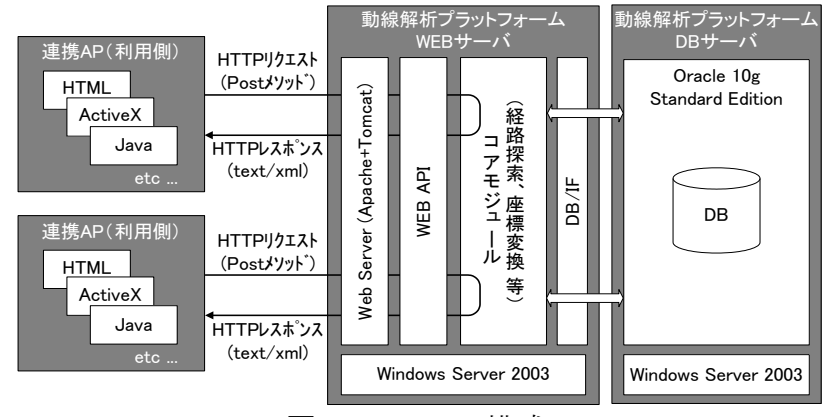

表-6 実験システムの諸元

\begin{tabular}{c|c|c}
\hline & Web サーバ & DB サーバ \\
\hline ミドル & Apache 2.2 .3 & Oracle Standard Edition \\
ウェア & Tomcat 6.0.24 & $10 \mathrm{~g}$ \\
\hline OS・ハ & OS: Windows Server 2003 & OS: Windows Server 2003 \\
Cドウ & CPU: インテル Xeon & CPU: インテル Xeon \\
エア & $2.4 \mathrm{GHz} \times 16$ & $1.87 \mathrm{GHz} \times 2$ \\
& メモリ: 4GB & メモリ: $4 \mathrm{~GB}$ \\
\hline
\end{tabular}

\section{(2) 各機能の速度}

次にここでは，各基本的なWebAPIの処理速度の 結果をまとめた。まずは表-7では，表-3で挙げた各 WebAPIに対し，複数回のリクエストを投げ，平均 的な応答速度をまとめたものである。任意の位置か ら道路上の最近隣点を返す"GetNearestRoadPoint"は， 他のAPIに比べるとシンプルな機能であるため，1 秒以内となっている。一方で，"GetRoadRoute"や "GetRailRoute"は近隣の道路や鉄道ネットワークを 探しつつ経路探索を行うため，数秒程度かかる。さ らに，"GetMixedRoute"や"GetSTInterpolatedPoints"な どは，いくつかの交通モードが混じった経路を返し たり，時空間内挿を行い時間解像度（ここでは，1 分）に応じて間の座標を算出しているため，重い処 理で，10秒を超えている.

次に，とくに人の流れデータの時空間検索として よく用いられる"GetPIDList"について，検索条件に よって応答速度も変わり得るため, いくつか変化さ せて応答速度を算出したものが表-8である．検索時 の空間的な範囲は，一次〜三次メッシュの3 種類, 時間が2分，1時間，24時間の3種類とし，また，通 過と滞在のそれぞれを調べた．結果としては，当初 の想定どおり，空間的に狭く絞るほど，時間的に短 い間に絞るほど，検索速度は速くなる。また，滞在 の方が全時間その空間にいることを調べることが必 要になるため, 時間はかかっている.

表-7 基本機能の処理速度

\begin{tabular}{|c|c|c|c|}
\hline 各WebAPI & テスト内容 & 秒数 & 備考 \\
\hline GetNearestRoadPoint & \multirow{5}{*}{$\begin{array}{l}\text { 一次メッシュ内（5339：関東 } / 5033: \text { 四国）にラン } \\
\text { ダムに1000回の点（あるいは起終点）をとり実施 }\end{array}$} & $\begin{array}{l}0.79 \mathrm{~s} \\
/ 0.49 \mathrm{~s}\end{array}$ & $\begin{array}{l}1 \mathrm{~km} \text { 以内に近傍点が見つからないケース } \\
\text { がある（1000回中233回／771回）. }\end{array}$ \\
\hline GetRoadRoute & & $\begin{array}{l}5.83 \mathrm{~s} \\
/ 2.73 \mathrm{~s}\end{array}$ & $\begin{array}{l}\text { ルートが見つからない（起点または終 } \\
\text { 点の } 1 \mathrm{~km} \text { ぬ内に近傍点が見つからない） } \\
\text { ケースがある（1000回中 } 302 \text { 回 } / 651 \\
\text { 回）. 秒数はルートがある時の平均. }\end{array}$ \\
\hline GetRailRoute & & $\begin{array}{l}1.67 \mathrm{~s} \\
/ 3.00 \mathrm{~s}\end{array}$ & ルートが見つからないものはなかった \\
\hline GetMixedRoute & & $\begin{array}{l}15.35 \mathrm{~s} \\
/ 19.97 \mathrm{~s}\end{array}$ & - \\
\hline GetSTInterpolatedPoints & & $\begin{array}{l}15.35 \mathrm{~s} \\
/ 16.33 \mathrm{~s}\end{array}$ & $\begin{array}{l}\text { ルートが見つからないケースがある } \\
\text { (1000回中2回／6回）. }\end{array}$ \\
\hline GetPIDList & $\begin{array}{l}\text { 駅の通過人数を想定するようなもの） } \\
\text { ・時間検索 (10分) }\end{array}$ & $※$ & ※詳細は表-8を参照 \\
\hline GetFlowData & PIDを指定して24時間分のトリップを取得する & $0.56 \mathrm{~s}$ & インデクス作成時の值 \\
\hline GetDistributionData & $\begin{array}{l}\text { 一次メッシュ内（5339，98TKY／5033，97KCH） に } \\
\text { ランダムに1000回の中心点をとり実施 }\end{array}$ & $\begin{array}{l}0.36 \mathrm{~s} \\
/ 0.16 \mathrm{~s}\end{array}$ & $5 \mathrm{~km}$ 四方のデータ取得 \\
\hline GetDistributionImage & $\begin{array}{l}\text { 一次メッシュ内 }(5339,98 \mathrm{TKY} / 5033,97 \mathrm{KCH}) \text { に } \\
\text { ランダムに10回の中心点をとり実施 }\end{array}$ & $\begin{array}{l}142.5 \mathrm{~s} \\
/ 139.8\end{array}$ & $5 \mathrm{~km}$ 四方のデータ取得 \\
\hline
\end{tabular}


表-8 時空間検索（GetPIDList）に関する処理速度と検索時空間範囲の関係

\begin{tabular}{|c|c|c|c|c|c|c|c|}
\hline & \multirow{3}{*}{$\begin{array}{l}\text { 時間範囲 } \\
\text { 空間範囲 }\end{array}$} & \multicolumn{6}{|c|}{ 上段：検索結果の人数（人），下段：検索秒数（秒） } \\
\hline & & \multicolumn{2}{|c|}{$\begin{array}{c}2 \text { 分 } \\
(8 \text { 時 } \sim 8 \text { 時 } 1 \text { 分 } 59 \text { 秒 })\end{array}$} & \multicolumn{2}{|c|}{$\begin{array}{c}1 \text { 時間 } \\
(8 \text { 時〜 } \sim \text { 時 } 59 \text { 分 })\end{array}$} & \multicolumn{2}{|c|}{$\begin{array}{c}24 \text { 時間 } \\
(0 \text { 時〜 } 23 \text { 時 } 59 \text { 分 }) \\
\end{array}$} \\
\hline & & 通過 & 滞在 & 通過 & 滞在 & 通過 & 滞在 \\
\hline$x$ & $\begin{array}{c}\text { 一次メッシュ } \\
\text { (5339) }\end{array}$ & $\begin{array}{r}551,956 \\
/ 9.02\end{array}$ & $\begin{array}{r}551,518 \\
/ 13.22\end{array}$ & $\begin{array}{l}561,935 \\
/ 132.18\end{array}$ & $\begin{array}{l}546,619 \\
/ 169.58\end{array}$ & \multicolumn{2}{|c|}{ タイムアウト } \\
\hline $\begin{array}{l}\text { ツ } \\
\text { シ }\end{array}$ & $\begin{array}{l}\text { 二次メッシュ } \\
\text { (533945) }\end{array}$ & $\begin{array}{r}36,609 \\
/ 0.58 \\
\end{array}$ & $\begin{array}{r}35,577 \\
/ 1.14 \\
\end{array}$ & $\begin{array}{l}64,942 \\
/ 24.00\end{array}$ & $\begin{array}{l}27,625 \\
/ 23.02 \\
\end{array}$ & \multicolumn{2}{|c|}{ タイムアウト } \\
\hline ב & $\begin{array}{c}\text { 三次メッシュ } \\
(53394525) \\
\end{array}$ & $\begin{array}{r}763 \\
/ 0.05\end{array}$ & $\begin{array}{r}574 \\
/ 1.02\end{array}$ & $\begin{array}{l}7,212 \\
/ 4.56\end{array}$ & $\begin{array}{r}371 \\
/ 1.70 \\
\end{array}$ & $\begin{array}{r}23,818 \\
/ 111.05\end{array}$ & $\begin{array}{r}19 \\
/ 108.48\end{array}$ \\
\hline \multirow{3}{*}{$\begin{array}{l}\text { 緯 } \\
\text { 度 } \\
\text { 経 } \\
\text { 度 }\end{array}$} & $\begin{array}{c}\text { 中心座標（35.666669, 139.500001） } \\
\text { 矩形範囲（縦 } 74271 \mathrm{~m} \times \text { 横 91143m） }\end{array}$ & $\begin{array}{r}553,045 \\
/ 14.38\end{array}$ & $\begin{array}{r}552,590 \\
/ 12.38 \\
\end{array}$ & $\begin{array}{l}562,903 \\
/ 281.81\end{array}$ & $\begin{array}{l}547,659 \\
/ 279.42 \\
\end{array}$ & \multicolumn{2}{|c|}{ タイムアウト } \\
\hline & $\begin{array}{c}\text { 中心座標（35.708335, 139.687549） } \\
\text { 矩形範囲（縦 } 9279 \mathrm{~m} \times \text { 横 } 11314 \mathrm{~m} ） \\
\end{array}$ & $\begin{array}{r}36,651 \\
/ 1.78 \\
\end{array}$ & $\begin{array}{r}35,592 \\
/ 1.12 \\
\end{array}$ & $\begin{array}{l}64,945 \\
/ 40.38 \\
\end{array}$ & $\begin{array}{l}27,645 \\
/ 38.38 \\
\end{array}$ & \multicolumn{2}{|c|}{ タイムアウト } \\
\hline & $\begin{array}{l}\text { 中心座標 }(35.687503,139.69375) \\
\text { 矩形範囲（縦 } 928 \mathrm{~m} \times \text { 横 } 1134 \mathrm{~m} ）\end{array}$ & $\begin{array}{r}759 \\
/ 0.99\end{array}$ & $\begin{array}{r}575 \\
/ 0.19\end{array}$ & $\begin{array}{r}7174 \\
/ 7.88\end{array}$ & $\begin{array}{r}371 \\
/ 1.36\end{array}$ & $\begin{array}{r}23,692 \\
/ 179.64\end{array}$ & $\begin{array}{r}19 \\
/ 163.77\end{array}$ \\
\hline
\end{tabular}

また，応答時間の絶対值はやや広域のケースとし て時空間範囲を1時間，2次メッシュなどにした場合 は通過で24秒である。これはリアルタイムとはいか ないまでも様々な分析を行う実用上の観点からいく と有効だと思われる。ただし，時間範囲を24時間と してしまうと，1次メッシュや2次メッシュの範囲だ と，タイムアウト（300秒以上）となってしまう。 あまりに広域のケースだと今のところは難しいがこ うした検索範囲はもとのフルデータそのものに近い ものであり，別途一括ダウンロードで対応している。

\section{(3) 都市圏全体の人の流れデータ構築に要する時間}

ここでは，時空間検索のもととなる人の流れデー タセットやそれに関わるテーブル構築にどの程度時 間がかかっているかを, 平成10年度の東京都市圈 PTデータで概観する. 表-9はその処理に数を工程ご とにまとめたものである。最初は，PTデータはマ スターデータがゾーンであるため, それらをジオコ 一ディングし，緯度経度に変換したり，不明データ が含まれるPIDについては除外をする必要がある。 ここの部分では, PTの調査ゾーンからうまくジオ コーディングができないケースや不明データが多数 含まれる場合の処理がたまにもあるため,こうした エラーケースは手作業で補っている.

また，それ以降は基本的に自動処理となっている. まずは各ODの時空間位置や交通機関を記録してい るサブトリップ単位で, 時空間内挿を行っている. この時空間内挿はGetSTInterpolatedPointsなどの汎用 的なWebAPI というよりは，高速化のためにPT用に 特化したローカル関数で処理を行っているものの, 3ケ月程度かかっている。これは72万人で割ると 1 人 あたりに要する処理時間は約 10 秒となる（1人あた りのサブトリップは4～5つ程度である）。これには， サブトリップ中の移動を時空間内挿するだけではな く，停滞している時間帯も座標を埋めることにも時 間を費やしている。従って，各テーブルの作成時間 も数日ずつかかってしまうが，これらは後の時空間 検索を極力高速化するためには，やむを得ない処理 と考えている.
表-9 東京PTデータの処理工程

\begin{tabular}{|c|c|}
\hline 各工程 & 処理日数 \\
\hline $\begin{array}{l}\text { マスターデータからゾーンをジオコーディング } \\
\text { して緯度経度に変換やイレギュラーデータ除外 }\end{array}$ & $\begin{array}{c}\text { 数日 } \\
\text { (手作業有) }\end{array}$ \\
\hline $\begin{array}{l}\text { ジオコーディング済みPTデータから時空間内挿 } \\
\text { による人の流れデータの作成（約 } 72 \text { 万人分）※ }\end{array}$ & 84日 \\
\hline ワークテーブルの作成 & 14日 \\
\hline 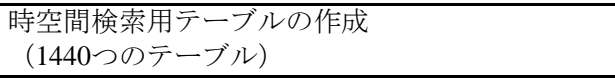 & 7日 \\
\hline 時空間検索用テーブルへのインデックスの作成 & 0.5 日 \\
\hline 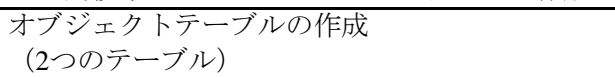 & 7日 \\
\hline チェック用テーブルの作成 & 7日 \\
\hline
\end{tabular}

※ただし，ネットワークを介さない内部関数としてAPIを利用

\section{(4) WebAPIの利用頻度}

このプラットフォームは無料で利用でき，2008年 7月以来，研究者を中心に150名程度のユーザー登録 行われている。ここではログに記録されているうち の2010年7月から2011年8月まで（ただし，2011年5 月は節電に配慮してサービスを停止）の約 1 年の各 WebAPIの利用状況を見て, 各処理関数の認知のさ れ方，使われる度合いを分析する。

実際にはプラットフォームの特性上，常時使って いることはなく, 該当データを検索, ダウンロード した後は各自の計算環境で使うことが多いが，各 WebAPIの利用回数をまとめたものが表-10である.

具体的には，道路上の最近隣点を取得する "GetNearestRoadPoint"や時間断面での人々の分布状 況を取得する"GetDistributionData"，該当する人の 1 日の移動状況を取り出す"GetFlowData"などが多く なっており，表-7で示した処理時間の短いものや， その機能が比較的シンプルで理解されやすいものに 利用が集まるようである。なお，表-10は現在は 「人の流れプロジェクト」の事務局自体が利用して いる回数も含まれており, 今後は分離した上での分 析も必要である. 
表-10 各WebAPIの利用回数

\begin{tabular}{|c|c|}
\hline API名 & 利用回数 \\
\hline GetNearestRoadPoint & 55,066 \\
\hline GetRoadRoute & 339 \\
\hline GetRailRoute & 70 \\
\hline GetMixedRoute & 21 \\
\hline GetSTInterpolatedPoints & 668 \\
\hline GetPIDList & 1,976 \\
\hline GetFlowData & 284,638 \\
\hline GetDistributionData & $1,976,487$ \\
\hline
\end{tabular}

\section{5. まとめ}

本研究では，都市空間における効率的な動線解析 の共通基盤のあり方について, 動線解析プラットフ オームを構築し，共用性が高いと思われる処理関数 をWebAPIとして定義・実装を行い，パフォーマン ステストを行い，実用上問題ないことを確認した. 今回は少ないサーバで実装していたが，今後，利用 の増加, さらなる高速化に備えてサーバー側の分散 化等を図っていくとともに，継続的にユーザーの利 用状況等の分析も行ってみることとしたい.

\section{謝辞}

本研究では, 動線解析プラットフォームについては, 初期の構築時点で国土技術政策総合研究所情報基盤 研究室にお世話になりました。また, 東京都市圏パ ーソントリップデータについては，国土交通省のか たがたにお世話になりました。この場を借りてお礼 を申し上げます。また, 本研究は, 日本学術振興会 科学研究費若手研究 (A) の補助を受けています. ここに感謝の意を表します.

\section{付録}

注1)人の流れプロジェクト：

http://pflow.csis.u-tokyo.ac.jp/（アクセス：2011年10月 21 日).

注2)パーソントリップ調査 :

http://www.mlit.go.jp/crd/tosiko/w_pt/index.html（アクセ ス：2011年10月21日）。

注3) プローブパーソン研究会 :

http://www.probe-data.jp/（アクセス：2011年10月21日）.

注 4) Department for Transportation, UK. : The Use of GPS to Improve Travel Data., 2003.

http://www.dft.gov.uk/rmd/project.asp?intProjectID=10883

（アクセス：2011年 10月 21 日）。

注 5) Ram M. Pendyala. : Measuring Day-to-Day Variability

in Travel Behavior Using GPS Data., 2003.

http://www.fhwa.dot.gov/ohim/gps/index.html（アクセス : 2011 年 10 月 21 日).

注6) ビデオリサーチ社の屋外メディア総合調査(SOTO) : http://www.videor.co.jp/service/oohmedia/soto.htm（アクセ ス：2011年10月21日）。

注7) 新宿区における帰宅困難者対策報告書 :

http://www.city.shinjuku.tokyo.jp/bousai/kitakusien/kitaku.ht $\mathrm{ml}$ (アクセス：2011年10月21日）.

注8) 低炭素都市づくりガイドライン（案）

http://www.mlit.go.jp/crd/city_plan/teitanso.html（アクセ ス：2011年10月21日）。
注9) たとえば料金が公開されているものでは，(株マクロ ミルなど

注10) Google transit : www.google.co.jp/transit

注11) たとえばナビッピ位置情報ASPサービス（侏ナビッ ピドットコム) など

注12) DRM: Digital Road Map（財団法人デジタル道路地図 協会）：http://www.drm.jp/（アクセス：2011年10月21 日）。

注 13）駅すぱあと（株式会社ヴァル研究所）： http://ekiworld.net/（アクセス：2011年10月21日）。

注14) OpenStreetMap : http://www.openstreetmap.org/ (アク セス：2011年10月21日）。

\section{参考文献}

1) 国土交通省都市・地域整備局都市計画課都市交通調查 室 : 都市圈 PT 調查の経緯・実績と今後の課題, 交通工 学, Vol.37, No.2, pp.21-26, 2002.

2) 中村, 兵頭, 山村, 紺屋 : JICA 都市交通開発調査デー タベースの紹介一世界 11 都市のパーソントリップデー タ一, 交通工学, Vol.39, 増刊号, pp.39-43, 2004.

3) 交通/ $\mathrm{OOH}$ 活用パーフェクトガイド, 宣伝会議, 2007 年 1 月 25 日号別冊, 宣伝会議, 2007.

4) JR 東日本企画 : 移動者マーケティング動く標的（消費 編），宣伝会議，2000.

5) 島崎康信, 関本義秀, 柴崎亮介, 秋山祐樹：人の流れ による時間帯別人口と店舗数との相関関係についての 研究, 都市計画学会都市計画論文集, Vol.44, No.3, pp.781-786, 2009.

6) Ohkusa Y., \& Sunagawa, T. : Application of an individualbased model with real data for transportaation mode and location to pandemic influenza, Jounal of Infect Chemother, Vol.13, 380-389, 2007.

7) 江島啓介, 鈴木秀幸, 合原一幸 : 東京都市圈パーソン トリップ調査データに基づく新型インフルエンザ感染 伝播の数理モデリング, 運輸と経済, Vol.70, No.1, 54-62, 2010.

8) 羽藤英二：「交通を測る新技術 ヒト，モノ，環境」第 4 回 人の行動を測るプローブ調査の実施と展望, 交通 工学, Vol.39(2), pp.85-91, 2004.

9) 牧村和彦: 高度情報機器を用いた歩行者行動モニタリ ングと移動支援, 交通工学, Vol.35, No.4, pp.40-45, 2000.

10) 内田敬：人を対象とする位置特定ベース情報サービス の動向と交通工学への応用可能性, 交通工学, Vol.39, No.6, pp.31-38, 2004.

11) 今井龍一, 井星雄貴, 濱田俊一, 中村俊之, 牧村和彦 : 動 線データを用いたバス走行改善の検討支援に関する研 究, 土木計画学研究・講演集, Vol.43, 2011.

12) 嶋田実 : 米欧における交通渋滞予測のための携帯プロ 一ブ利用の動き，KDDI 総研 R\&A，2006 年 9 月第 1 号, 2006.

13) 八木浩一：広域災害時の交通状況監視を目的とした 4 帯電話基地局情報の解析手法の開発, 第 5 回 ITS シン ポジウム 2006, 2006.

14) Ratti, C., et al : Mobile Landscapes: using location data from cell phones for urban analysis, Environment and Planning B: Planning and Design, Vol. 33, No. 5, pp.727748, 2006. 
付録表-1 道路の経路選択時に用いた道路種別，移動手段ごとの移動速度

\begin{tabular}{|c|c|c|c|c|c|c|c|c|c|c|}
\hline \multirow[t]{2}{*}{ 道路種別 } & \multirow{2}{*}{$\begin{array}{c}\text { 道路種別コ } \\
\text {-ド }\end{array}$} & \multicolumn{9}{|c|}{ 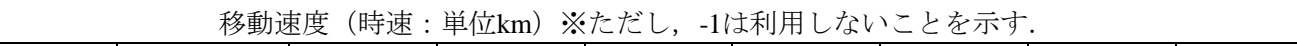 } \\
\hline & & 徒歩 & 自転車 & $\begin{array}{c}\text { 原動機付 } \\
\text { 自転車 }\end{array}$ & $\begin{array}{l}\text { 自動二輪 } \\
\text { タクシー }\end{array}$ & 乗用車 & 軽乗用車 & $\begin{array}{l}\text { 貨物 } \\
\text { 自動車 }\end{array}$ & $\begin{array}{c}\text { 自家用 } \\
\text { バス }\end{array}$ & 路線バス \\
\hline 都市間高速 & 1 & -1 & -1 & -1 & 80 & 100 & 100 & 100 & 90 & 90 \\
\hline 都市高速 & 2 & -1 & -1 & -1 & 60 & 70 & 70 & 70 & 60 & 60 \\
\hline 国道 & 3 & 6 & 10 & 30 & 50 & 50 & 50 & 50 & 50 & 50 \\
\hline 主要地方道 & 4 & 6 & 10 & 30 & 40 & 45 & 45 & 45 & 45 & 45 \\
\hline 主要市道 & 5 & 6 & 10 & 30 & 40 & 45 & 45 & 45 & 45 & 45 \\
\hline 県道 & 6 & 6 & 10 & 30 & 40 & 40 & 40 & 40 & 40 & 40 \\
\hline 市道 & 7 & 6 & 10 & 30 & 30 & 30 & 30 & 30 & 30 & 30 \\
\hline 街路 & 8 & 6 & 10 & 30 & 30 & 30 & 30 & 30 & 30 & 30 \\
\hline その他 & 9 & 6 & 10 & 30 & 30 & 30 & 30 & 30 & 30 & 30 \\
\hline
\end{tabular}

15) Horanont, T., \& Shibasaki, R. : An Implementation of Mobile Sensing for Large-Scale Urban Monitoring, Proceedings of the International Workshop on Urban, Community, and Social Applications of Networked Sensing Systems (UrbanSense 2008), 2008.

16) 関本義秀, Horanont, T., 柴崎亮介 : < 解説 $>$ 携帯電話 を活用した人々の流動解析技術の潮流, 情報処理,

Vol.52, No.12, pp.1522-1530, Dec. 2011.

17) Yoshihide Sekimoto, Ryosuke Shibasaki, Hiroshi Kanasugi, Tomotaka Usui and Yasunobu Shimazaki, PFLOW: Reconstruction of people flow recycling large-scale social survey data, IEEE Pervasive Computing, Vol.10, No.4, pp.27-35, Oct.-Dec. 2011.
18) Wolfson, O., Sistla, A.P., Xu, B., Zhou, J., Chamberlain, S. (1999). DOMINO: databases for moving objects tracking. Proceedings of ACM Symposium on the Management of Data (SIGMOD), Philadelphia, pp. 547-549.

19) 小島英史，羽藤英二：プローブパーソンデータによる オンラインマッチングアルゴリズム，土木計画学研究 発表会・講演集, Vol.29 (CD-ROM), 2004.

20) 三輪富生, 木内大介, 山本俊行, 薄井智貴, 森川高 行 : 低コストプローブカーデータのオンラインマップ マッチング手法の開発, 交通工学, Vol.44, No.3, pp.100-110, 2009.

(2011. 10. 21 受付)

\section{STUDY OF INFORMATION PLATFORM FOR PEOPLE FLOW ANALYSIS IN URBAN AREA}

\section{Yoshihide SEKIMOTO, Tomotaka USUI, Hiroshi KANASUGI and Yusuke MASUDA}

This study considers an information platform for people flow analysis in urban area. The platform, which can keep a certain quality of location data of many people even in the buisuiness operation scene, aims at an acceleration of person traffic investigation or real-time monitoring, by the reduction of data processing loads which have been done in various urban managers.

Concretely we design WebAPI for web service supporting various kinds of analysis such as map matching or spatio-temporal interpolation etc. for people flow, after arrangement of the needs of location data of people in a public and private field, and the seeds such as existing technologies and problems. Actually we implement the platform which can process the data effectively, and measure the performance of each WebAPI function, and analyse application status of registered users. 